\title{
Intake of different food sources in the first zoeae stages of Macrobrachium tenellum (Decapoda: Palaemonidae)
}

\author{
Manuel A. Vargas-Ceballos ${ }^{1}$, Daniel Badillo-Zapata ${ }^{1,3}$, Olimpia Chong-Carrillo ${ }^{1}$ \\ Jesús T. Ponce-Palafox ${ }^{2}$, Luis Héctor Hernández-Hernández ${ }^{4}$ \& Fernando Vega-Villasante ${ }^{1}$ \\ ${ }^{1}$ Laboratorio de Calidad de Agua y Acuicultura Experimental, Centro de Investigaciones \\ Costeras, Universidad de Guadalajara, Jalisco, México \\ ${ }^{2}$ Universidad Autónoma de Nayarit, Laboratorio de Bioingeniería Costera \\ Escuela Nacional de Ingeniería Pesquera, Nayarit, México \\ ${ }^{3}$ Consejo Nacional de Ciencia y Tecnología, Cátedras CONACYT, México \\ ${ }^{4}$ Laboratorio de Producción Acuícola (Acuario), Universidad Nacional Autónoma de México \\ Facultad de Estudios Superiores, Iztacala, México \\ Corresponding author: Fernando Vega-Villasante (fernandovega.villasante @ gmail.com)
}

\begin{abstract}
The objective of this work was to assess the acceptance of live and inert food by Macrobrachium tenellum during the early larval stages. The larvae were obtained by collecting wild ovigerous females in the Ameca River in the State of Jalisco, Mexico. Eight treatments (diets) were used to feed the larvae: D1, control (fasting); D2, micro-pulverized food $\left(\right.$ Purina $^{\circledR}$ ); D3, living, newly hatched nauplii of Artemia franciscana (INVE ${ }^{\circledR}$, Salt Lake City, Utah, USA); D4, commercial paste containing microalgae (Instant Algae Rotifer Diet ${ }^{\circledR}$ ); D5, water extracted from a biofloc system; D6, cooked egg yolk; D7, newly hatched and frozen nauplii of $A$. franciscana $\left(\mathrm{INVE}^{\circledR}\right.$, Salt Lake City, Utah, USA); D8, nutritional supplement for shrimp larvae (Epifeed LH1 ${ }^{\circledR}$ ). Treatments D2, D5, D6 and D8 showed traces of food in the digestive system. The larvae did not consume D3 and D7 treatments. The diets that had more acceptance were micro-pulverized food, a nutritional supplement for shrimp larvae Epifeed ${ }^{\circledR}$ LH1, cooked egg yolk, and biofloc water.
\end{abstract}

Keywords: prawn; zoea; Artemia; food intake; inert food; nutrition; aquaculture

Aquaculture is one of the fastest-growing economic activities worldwide, requiring constant improvements in the management of different aquatic species. Among crustaceans, the genus Macrobrachium (Bate, 1868) is comprised of 243 species of freshwater prawns (De Grave \& Fransen, 2011), of which only some have proven to be of interest for aquaculture (GarcíaGuerrero et al., 2013). Nowadays, the global demand for prawns is mainly met by the Asian species $M$. rosenbergii, which is widely cultivated around the world (New, 2009). However, this species is listed as exotic, which means that it might cause ecological damage if introduced to countries outside of its natural range of distribution (Yan et al., 2001). The use of native species in aquaculture has several advantages: the animals adapt more quickly to the environment, the environmental impact of aquaculture activities is mini- mized, and the product has better acceptance in local markets (Yamasaki-Granados et al., 2013).

Macrobrachium tenellum is a species native to Mexico of high commercial interest; however, the scarcity of studies on the larval stages of this species has not allowed cultivating it for commercial purposes. Nutritional factors are among the most important factors in the larval development of decapod crustaceans such as prawns. The larval stage, which is the most critical developmental stage for crustaceans, is when they start feeding exogenously, after the absorption of the yolk sac (Luna-Figueroa et al., 2010). However, knowledge about the digestive processes and nutritional requirements of prawn larvae is very limited (Araujo \& Valenti, 2007). According to Barros \& Valenti (2003b), larvae of different species of Macrobrachium show different stages of development,

Corresponding editor: Mauricio Laterça 
different morphology, behavior, and nutritional needs; furthermore, they generally have small buccal openings and a small yolk reserve. They need an exogenous food source in the first few days after hatching. The main source of live food in commercial crustacean larviculture is newly hatched Artemia nauplii (Barros \& Valenti, 2003a). The use of this type of live food for prawn larval feeding has several advantages, including easy handling and high content of essential nutrients (Lavens et al., 2000). However, some authors have reported that Artemia nauplii do not provide the nutrients required during the last larval stages of $M$. rosenbergii, and thus recommend the use of dietary supplements (Valenti et al., 1998; Valenti \& Daniels, 2000; Barros \& Valenti, 2003a).

Moreover, some crustacean species are not strictly carnivores during all larval stages (Araujo \& Valenti, 2007). For these reasons, some authors have suggested the use of alternative food sources (live and inert) as a complement or replacement of Artemia nauplii in crustacean larviculture (Alam et al., 1995a,b; Silva \& Rodriguez, 1997; Barros \& Valenti, 2003a). The objective of the present study was to assess the intake of live and inert food by M. tenellum in the early larval stages.

The study was carried out in the Laboratorio de Calidad de Agua y Acuicultura Experimental of Universidad de Guadalajara (LACUIC), located at the Centro Universitario de la Costa in Puerto Vallarta, Jalisco, Mexico. The larvae were obtained by collecting wild ovigerous females in the Ameca River, Jalisco, Mexico. Ovigerous females carrying stage III eggs (Wehrtmann, 1990) were selected and separated individually into experimental units of $40 \mathrm{~L}$, with water adjusted to salinity of 10 , an average temperature of $29.0 \pm 0.5^{\circ} \mathrm{C}$ and constant aeration; they were fed with a commercial feed with $35 \%$ protein and $8 \%$ fat $\left(\right.$ Purina $\left.^{\circledR}\right)$. After the embryos hatched, the larvae were removed and placed in reservoirs with the same characteristics of salinity and temperature as before. Eight treatments (diets) were used to feed the larvae: D1, control (fasting); D2, micro-pulverized $(<200 \mu \mathrm{m})$ feed for marine shrimp (48\% crude protein) $\left(\right.$ Purina $\left.^{\circledR}\right)$; D3, newly hatched, living nauplii of Artemia franciscana (INVE ${ }^{\circledR}$, Salt Lake City, Utah, USA); D4, commercial microalgae concentrate (Instant Algae Rotifer Diet $\left.^{\circledR}\right)$; D5, water extracted from a biofloc system; D6, cooked egg yolk; D7, frozen, newly hatched nauplii of A. franciscana (INVE ${ }^{\circledR}$, Salt Lake City, Utah, USA); D8, inert diet for marine shrimp larvae (Epifeed LHF $1^{\circledR}$ ). The production of nauplii of A. franciscana was performed according to VegaVillasante et al. (2013). For the assays to measure food intake, 24 plastic containers ( $150 \mathrm{~mL}$ capacity) were used,
Table 1. Food detected in the different areas of the digestive tract of zoea II larvae of Macrobrachium tenellum. X represents the presence of food particles. D1: control (fasting); D2: micro-pulverized food (Purina ${ }^{\circledR}$ ); D3: newly hatched, living nauplii of Artemia franciscana (INVE ${ }^{\circledR}$, Salt Lake City, Utah, USA); D4: commercial concentrate of microalgae (Instant algae ${ }^{\circledR}$ ); D5: water extracted from a biofloc system; D6: cooked egg yolk; D7: newly hatched and frozen nauplii of A. franciscana. (INVE ${ }^{\circledR}$, Salt Lake City, Utah, USA); D8: inert diet for shrimp larvae (Epifeed $\mathrm{LH} 1{ }^{\circledR}$ ).

\begin{tabular}{ccc}
\hline Treatments & Stomach & Intestine \\
\hline D1 & - & - \\
D2 & $\mathrm{X}$ & $\mathrm{X}$ \\
D3 & - & - \\
D4 & - & - \\
D5 & $\mathrm{X}$ & \\
D6 & $\mathrm{X}$ & \\
D7 & - & - \\
D8 & $\mathrm{X}$ & $\mathrm{X}$ \\
\hline
\end{tabular}

each with $100 \mathrm{~mL}$ of water adjusted to salinity of 10 , previously prepared by mixing marine and purified freshwater. Ten larvae were used (collected one day after hatching, zoea I) per experimental unit. Each treatment was performed in triplicate. The larvae were deprived of food for $2 \mathrm{~h}$ and then fed once with different treatments. After $30 \mathrm{~min}$, all larvae were collected, put in a Petri dish, and examined under a stereomicroscope to determine the presence of food particles inside the digestive tract. The digestive content was classified as follows: a) absence of food (both the stomach and the intestine were empty); b) the presence of food (the stomach and the intestine were full or partially full). The acceptability (\%) of the treatments was determined by the ratio between the number of larvae with the presence of food in the stomach or intestine, and the total number of larvae observed. One-way ANOVA was used to compare the data obtained in this experiment (after verifying normality and homoscedasticity of variances), followed by Tukey's test. The significance level was set at $P<0.05$. All the analyses were performed using the software "SigmaPlot" (version 11.0).

Table 1 shows the results obtained by feeding larvae of $M$. tenellum with the different diets evaluated. Treatments D2, D5, D6 and D8 showed traces of food in some sections of the digestive tract (Fig. 1). Treatments D2 and D8 showed traces of food in the stomach and the intestine in the first $30 \mathrm{~min}$ of exposure. Treatments D5 and D6 showed food particles only in the stomach. Treatments D3, D4 and D7 were not consumed by the larvae (zoea II). The percentage of acceptance differed significantly for each treatment 


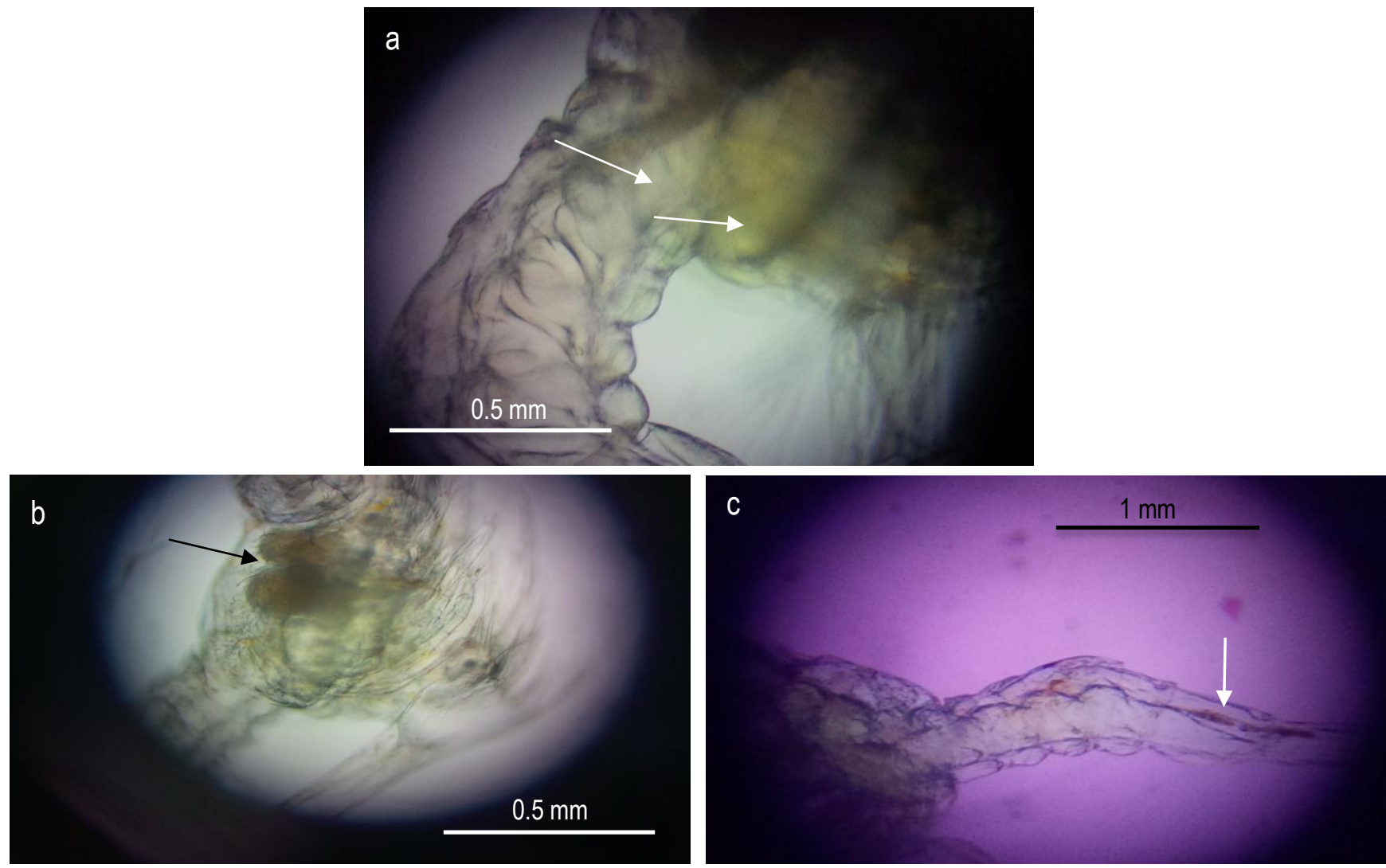

Figure 1. Food consumed by zoea II larvae of Macrobrachium tenellum: a) hepatopancreas and the first portion of the hindgut with commercial micro-pulverized food, b) hepatopancreas with Epifeed LHI ${ }^{\circledR}$ food, c) final portion of the hindgut with Epifeed LHI ${ }^{\circledR}$ particles (the arrows in every case show the mentioned area).

(ANOVA, $\mathrm{F}=6.78$, d.1. $=3, P=0.01$ ) (considering only the treatments that had some degree of acceptance) (Fig. 2). Treatments D2, D5 and D8 $(93.3,76.7,80 \%)$ were statistically similar. Treatment D6 (43.3\%) was significantly different from D2 (Tukey, $P=0.01$ ) and D5 from D8 (Tukey, $P>0.05$ ).

The larval stage is one of the most critical in the culture of prawns because, after consuming the yolk reserves, feeding becomes a priority. Anger \& Hayd (2009) reported that during the initial phase of larval development, the larvae use their fat reserves not only in the absence of food but also when enough food is available, although in the latter case, they use their fat reserves more slowly. Programmed lipid degradation ensures that maternal energy, previously invested in embryos, is eventually converted into metabolic energy and in the precursors that are necessary for the synthesis of new tissues. Some prawn species, such as $M$. amazonicum and $M$. rosenbergii, can feed on other organisms (carnivorous behavior) from the second day after consuming their yolk sac (Barros \& Valenti, 2003a; Araujo \& Valenti, 2007). The use of different

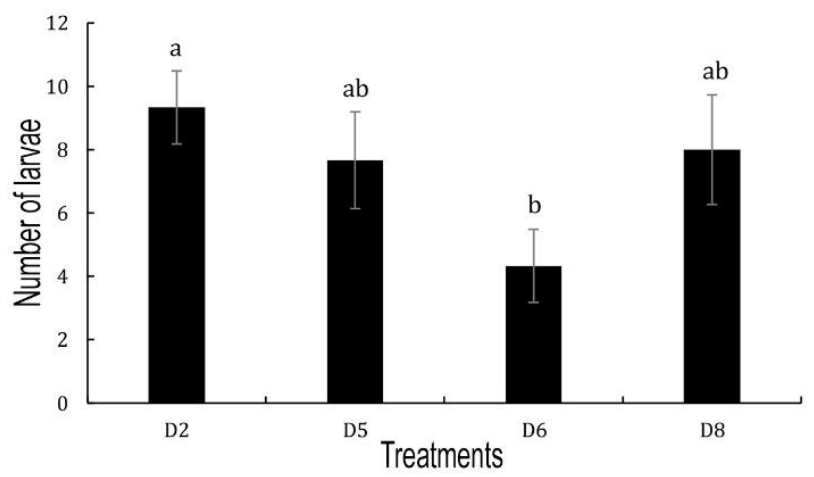

Figure 2. The number of Macrobrachium tenellum larvae that had food remains in some sections of the digestive system (in the accepted diets). The values of the treatments are presented in triplicate, mean \pm standard deviation. Different letters indicate significant differences $(P>0.05)$.

nutritional sources by $M$. rosenbergii during the larval stage (zoea II) has already have been studied, but the larvae of other species do not consume the same type of diet (Lavens et al., 2000). Anger \& Hayd (2009) re- 

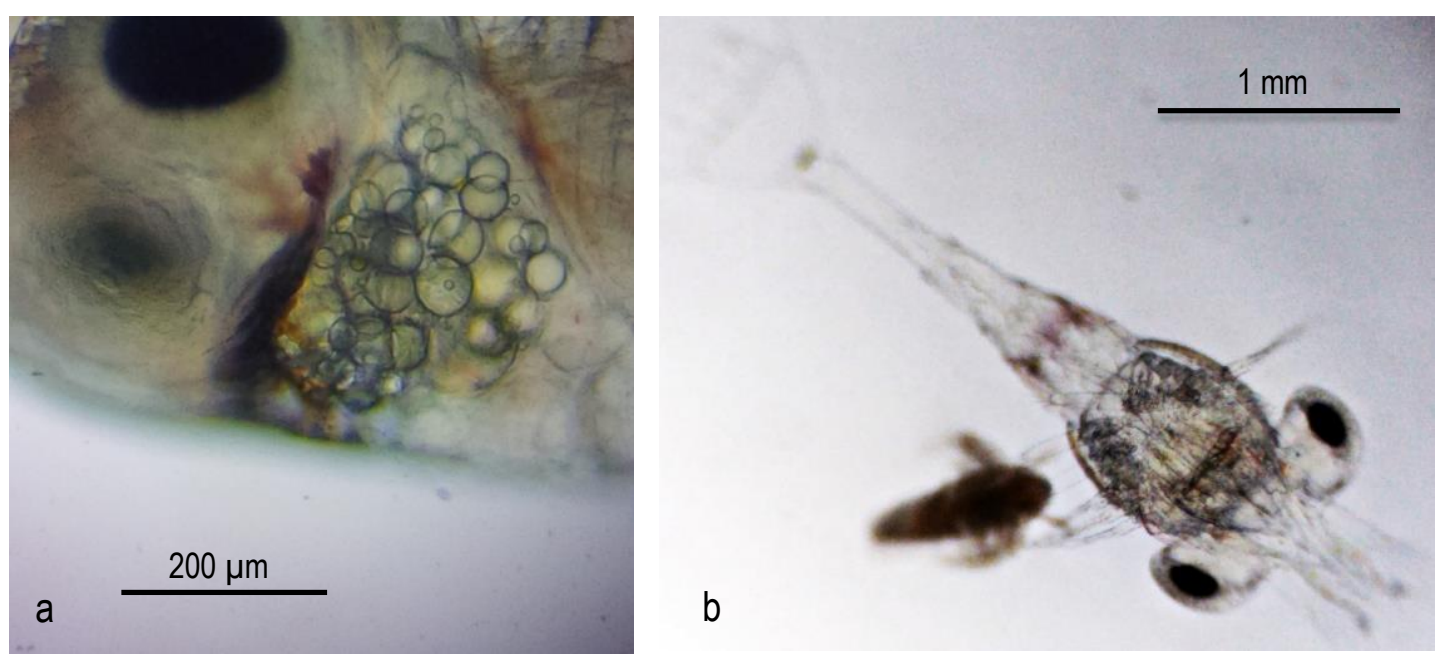

Figure 3. a) Lipid supplies of zoea I of Macrobrachium tenellum, b) Artemia franciscana nauplii and zoea II of Macrobrachium tenellum.

ported that in the early larval stages, Palaemonidae shrimps, including some marine species, often feed partially on plankton, while other shrimps pass through lecithotrophic phases during facultative stages.

In the present study, the zoea I stage did not consume food, regardless of the treatment. This feeding behavior has been mentioned by other authors who reported that the zoea I of $M$. rosenbergii and $M$. amazonicum are lecithotrophic and survive on yolk reserves during the first days (Barros \& Valenti, 1997; Araujo \& Valenti, 2007). The zoea I of M. tenellum was found to have some lipid reserves in the cephalothoracic region that allows it to grow into the next stage without exogenous feeding (Fig. 1). The first record of the presence of food in the intestine of $M$. tenellum larvae occurred in the zoea II stage, as digested food particles were observed moving from the hepatopancreas towards the hindgut (Fig. 3) which agrees with the reports of Barros \& Valenti (2003a) and Anger \& Hayd (2009), who determined that the early stages of larval development of $M$. rosenbergii and $M$. amazonicum depend little on exogenous food sources, even though zoea II shows intermittent lecithotrophic behavior, being able to accept or reject exogenous feeding. Of the evaluated treatments, the ones that showed greater acceptance (traces of food in any section of the digestive tract) by zoea II were D2, D5, D6 and D8. Except for treatment D5, the treatments that were accepted by the larvae consisted of inert food.

However, inert diets were found to be too inefficient, mainly due to the lack of knowledge about the nutritional needs of the larvae (Sorgeloos \& Léger, 1992). Barros \& Valenti (2003a) mentioned that, in inert diets, the size of food particles, their consistency, texture and density could influence their acceptability to larvae. These same authors reported that the level of the water column could affect the frequency of food intake in zoea II of $M$. rosenbergii, mainly by allowing particles to disperse better and remain in suspension for more extended periods, increasing the probability of being caught and eaten by larvae. Currently, in addition to providing Artemia nauplii throughout the larval cycle, most commercial hatcheries of $M$. rosenbergii provide a wet diet known as egg flan (Levens et al., 2000). In the present study, the egg yolk treatment was accepted by larvae of $M$. tenellum.

The larvae fed with water extracted from the biofloc system (D5 treatment) had some food particles in the digestive tract. It is known that water from a mature biofloc culture will probably contain rotifers (Loureiro et al., 2012) and nematodes (Ray et al., 2010) as well as bacteria and yeasts (Monroy-Dosta et al., 2013). Barros \& Valenti (2003a) suggested that penaeid larvae have a good rate of survival and acceptable development when cultured with rotifers. Silva \& Rodriguez (1997) concluded that in the larviculture of M. rosenbergii, $34 \%$ of Artemia nauplii could be replaced with the nematode Panagrellus redivivus from larval stage V, and up to $66 \%$ after stage VII.

This experimental essay verified that the early larval stages of $M$. tenellum (zoea II) could not eat $A$. franciscana nauplii due to their size, as it is practically impossible for larvae to capture the nauplii and feed on them. However, Artemia nauplii constitute the main live food source in commercial crustacean larviculture (Barros \& Valenti, 2003a) and are commonly used in the larviculture of $M$. rosenbergii (Levens et al., 2000; Barros \& Valenti, 2003b; Nhan et al., 2010). Similarly, 
Gomes et al. (2014) mentioned that it is possible to feed the postlarvae of M. equids feed with Artemia nauplii. It is worth noting that the first larvae of $M$. rosenbergii (2.2 mm) (Levens et al., 2000) and M. equidens (1.9-2 $\mathrm{mm}$ ) (Ngoc-Ho, 1976) are larger than the zoea I of $M$. tenellum $(1.5-1.7 \mathrm{~mm})$.

In the present study, Artemia nauplii were frozen in order to stop their motility and then supplied to larvae of $M$. tenellum, but they were not able to eat them. Similar results were found by Yamasaki-Granados et al. (2013), who reported that M. americanum failed to feed on frozen Artemia nauplii. Feeding M. tenellum larvae with newly hatched nauplii of Artemia did not work, as has been reported for other Macrobrachium species, at least during the first larval stages (zoea I and zoea II). Micro pulverized food, water from a biofloc system, and Epifeed $\mathrm{LH} 1{ }^{\circledR}$ represents an alternative for feeding $M$. tenellum larvae, at least in their early stages. However, further study is required.

\section{REFERENCES}

Alam, M.J., Ang, K.J. \& Begum, M. 1995a. Replacement of Artemia with Moina micrura in the rearing of freshwater shrimp larvae. Aquaculture International, 3: 243-248.

Alam, M.J., Ang, K.J. \& Begum, M. 1995b. Use of egg custard augmented with cod liver oil and Moina micrura on production of freshwater prawn postlarvae. Aquaculture International, 3: 249-259.

Anger, K. \& Hayd, L. 2009. From lecithotrophy to planktotrophy: ontogeny of larval feeding in the Amazon River prawn Macrobrachium amazonicum. Aquatic Biology, 7: 19-30.

Araujo, M.C. \& Valenti, W.C. 2007. Feeding habit of Amazon River prawn Macrobrachium amazonicum larvae. Aquaculture, 265: 187-193.

Barros, H.P. \& Valenti, W.C. 1997. Comportamento alimentar do camarão de água doce, Macrobrachium rosenbergii (De Man) (Crustacea, Palaemonidae) durante a fase larval: análise qualitativa. Revista Brasileira de Zoologia, 14: 785-793.

Barros, H.P. \& Valenti, W.C. 2003a. Food intake of Macrobrachium rosenbergii during larval development. Aquaculture, 216: 165-176.

Barros, H.P. \& Valenti, W.C. 2003b. Ingestion rates of Artemia nauplii for different larval stages of Macrobrachium rosenbergii. Aquaculture, 217: 223233.

De Grave, S. \& Fransen, C.H.J.M. 2011. Carideorum catalagus: the new species of the dendrobranchiate, stenepodidean, procaridean, and caridean shrimps (Crustacea: Decapoda). Zoologische Mededelingen, 85(9): 195-589.
García-Guerrero, M.U., Becerril-Morales, F., VegaVillasante, F. \& Espinosa-Chaurand, L.D. 2013. Los langostinos del género Macrobrachium con importancia económica y pesquera en América Latina: conocimiento actual, rol ecológico y conservación. Latin American Journal of Aquatic Research, 41(4): 651-675.

Gomes, J.N., Abrunhosa, F.A., Costa, A.K. \& Maciel, C. 2014. Feeding and larval growth of an exotic freshwater prawn Macrobrachium equidens (Decapoda: Palaemonidae), from northeastern Pará, Amazon Region. Anais da Academia Brasileira de Ciências, 86(3): 1525-1535.

Levens, P., Thongrod, S. \& Sorgeloos, P. 2000. Larval prawn feeds and the dietary importance of Artemia. In: New, M.B. \& Valenti, W.C. (Eds.). Freshwater prawn culture. Blackwell, Oxford, pp. 91-111.

Loureiro, K.C., Wilson, W.J. \& Abreu, P.C. 2012. Utilização de protozoários, rotíferos e nematódeos como alimento vivo para camarões cultivados no sistema BFT. Atlântica, Rio Grande, 34(1): 5-12.

Luna-Figueroa, J., Vargas, Z.T. de J. \& Figueroa, T.J. 2010. Alimento vivo como alternativa en la dieta de larvas y juveniles de Pterophyllum scalare (Lichtenstein, 1823). Avances en Investigación Agropecuaria, 14(3): 63-72.

Monroy-Dosta, M. del C., De Lara-Andrade, R., CastroMejía, J., Castro-Mejía, G. \& Coelho-Emerenciano, M.G. 2013. Composición y abundancia de comunidades microbianas asociadas al biofloc en un cultivo de tilapia. Revista de Biología Marina y Oceanografía, 48(3): 511-520.

New, M. 2009. History and global status of freshwater prawn farming. In: New, M.B., Valenti, W.C., Tidwell, J.H., D'Abramo, L.R. \& Kutty, M.N. (Eds.). Freshwater prawns: biology and farming. WileyBlackwell, Oxford.

Ngoc-Ho, N. 1976. The larval development of the prawn Macrobrachium equidens and Macrobrachium sp. (Decapoda: Palaemonidae), reared in the laboratory. Journal of Zoology, 178: 15-55.

Nhan, D.T., Wille, M., Hung, L.T. \& Sorgeloos, P. 2010. Effects of larval stocking density and feeding regime on larval rearing of giant freshwater prawn (Macrobrachium rosenbergii). Aquaculture, 300: 8086.

Ray, A.J., Lewis, B.L., Browdy, C.L. \& Leffler, J.W. 2010. Suspended solids removal to improve shrimp (Litopenaeus vannamei) production and an evaluation of a plant-based feed in minimal-exchange, superintensive culture systems. Aquaculture, 299(1-4): 8998. 
Silva, F.M. \& Rodriguez, J.B.R. 1997. Efeito da substituição de Artemia sp. pelo nematóide Panagrellus redivivus sobre o crescimento e sobrevivência larval do camarão de água doce (Macrobrachium rosenbergii). Boletim do Instituto de Pesca, 24: 35-48.

Sorgeloos, P. \& Léger, P. 1992. Improved larviculture outputs of marine fish, shrimp, and prawn. Journal of the World Aquaculture Society, 23: 251-264.

Valenti, W.C. \& Daniels, W.H. 2000. Recirculation hatchery systems and management. In: New, M.B. \& Valenti, W.C. (Eds.). Freshwater prawn culture. Blackwell, Oxford, pp. 69-90.

Valenti, W.C., Mallasen, M. \& Silva, C.A. 1998. Larvicultura em sistema fechado dinâmico. In: Valenti, W.C. (Ed.). Carcinicultura de água doce: tecnologia para produção de camarões. FAPESP/ IBAMA, Brasília, pp. 112-139.

Received: 16 April 2019; Accepted: 10 September 2019
Vega-Villasante, F., Ruiz-González, L.E., GuerreroGalván, S.R. \& Guzmán-Dávalos, L. 2013. Evaluación de la toxicidad de Psilocybe cubensis (Agaricales, Basidiomycota) sobre Artemia franciscana (Crustacea, Anostraca). Revista Iberoamericana de Micología, 30(1): 54-56.

Wehrtmann, I.S. 1990. Distribution and reproduction of Ambidexter panamense and Palaemonetes schmittii in Pacific Costa Rica (Crustacea, Decapoda). Revista de Biología Tropical, 38(2A): 327-329.

Yamasaki-Granados, S., García-Guerrero, M., VegaVillasante, F., Castellanos-León, F., Cavalli, R. \& Cortés-Jacinto, E. 2013. Experimental culture of the river prawn Macrobrachium americanum larvae (Bate, 1868), with emphasis on the stocking density effect on survival. Latin American Journal of Aquatic Research, 41(4): 793-800.

Yan, X., Zhenzu, L., Gregg, W. \& Dianmo, L. 2001. Invasive species in China - an overview. Biodiversity and Conservation, 10: 1317-1341. 